\title{
Need Analysis of Learning Model of History Integrated with Leadership Values of Mangkunegara I through Reflective Pedagogy Paradigm Yoel Kurnawan Raharjo ${ }^{1}$, Sariyatun ${ }^{2}$, Warto ${ }^{3}$
}

\begin{tabular}{l} 
ARTICLE INFO \\
\hline Article History: \\
Received 03.03.2019 \\
Received in revised form \\
24.06.2019 \\
Accepted \\
Available online 01.10 .2019
\end{tabular}

\begin{abstract}
History learning has strategic objectives as the formation of dignified national character and civilization. This is inseparable from the function of history learning as transfer of knowledge and transfer of values. However, the strategic objectives and functions in the field are not achieved because of two issues, namely non-innovative learning models and inappropriate learning approaches. This study wanted to observe the conditions of history larning occurred at school. The location of the research was at SMA Kolese De Britto, Yogyakarta. This school was chosen because it had the characteristics, namely leadership based school and the learning approach, namely reflective pedagogy paradigm. This study used the qualitative method with the approach of case study. The techniques of collecting data included deep interview, study of literature, questionnaire and observation. The objectives of this study were 1) to observe the history learning at school, 2) to analyze the product need of the learning model of history. The result of the research showed that it was necessary to have the product of the learning model of history integrated with the leadership values of Mangkunegara I through Reflective Pedagogy Paradigm in accordance with the characteristic of the school, namely "leadership" based school.
\end{abstract}

(c) IJERE. All rights reserved

Keywords:

Need Analysis, history learning model, leadership values. INTRODUCTION

Law Number 20 of 2003 concerning the Indonesian National Education System stated that "National Education functions to develop and form dignified national character and civilization in order to educate the nation's life, aiming at developing potential students to become human beings who believe and fear the Almighty God, are noble, healthy, knowledgeable, capable, creative, independent, and become democratic and responsible citizens (The National Education System in Law Number 20 Article 3, 2003).

The mandate of the Law of the National Education System is translated into the process of implementing education in Indonesia, both at the macro level and the micro level. The implementation of education at the macro level refers to the curriculum and education policies made by the authorized institutions. Klein calls the curriculum as "heart of education" because the implementation of education refers to the applied curriculum (Hasan, 2012). On the other hand, the implementation of education at the micro level refers to the process of teaching and learning at schools. It is necessary to understand the implementation of education at the macro level and the micro level which is an interrelated relationship to achieve the objectives of the national education as stated in Law Number 20 of 2003 Article 3 concerning the National Education System.

The current curriculum implemented in Indonesia is the 2013 curriculum. This is a comprehensive and adaptive curriculum to face the 21st century. In the 21st century, the change of paradigm occurs to influence the implementation of education. Education must be able to combine knowledge and skills. In the education of the 21st century, there are five "life and career skills" consisting of 1) Flexibility and Adaptability 2) Initiative and Self-Direction 3) Social and Cross-Cultural Skills 4) Productivity and Accountability 5) Leadership and Responsibility (www.P21.org). Leadership is one of the five life and career skills that is important and must be mastered by students. This is inseparable from the leadership crisis occurred in Indonesia due to the decline in the character values. In the national level, the leaders who are able to give good examples and have characteristics of a statesman cannot be found out (Siswanto, 2013). The Public figures like political elites and bureaucrats provide bad examples, such as corruption, abuse of authority, demoralization, indiscretion and lack of paying attention to the society. Such behaviors done by the public figures do not provide the exemplary of the leadership values that are good for the younger generation, especially students. 
Raharjo,Y.K., Sariyatun \& Warto (2019). Need analysis of learning model of history integrated with leadership values of mangkunegara i through reflective pedagogy paradigm. International Journal of Educational Research Review,4(4),617-623.

Northouse (2013) defined leadership as the process in which an individual influences a group of individuals to achieve common goals. Mac Gregor (1978) stated that leadership is an embodiment of ambitions, aspirations of values that develop in the society so that leadership is one of the functions in the society's life that can realize the ambitions, aspirations, and values of the society. Yulk (1989) viewed that leadership can be seen by several approaches, namely power, behavior, outward, and situational approaches. This article tried to describe leadership with a behavioral perspective. This means that how an individual behaved and acted by having good leadership values.

The leadership values should be taught and integrated in the learning in the classroom to equip the lives of students in the future. Integration of the leadership values can be conducted in the history learning. This is inseparable from the objectives and functions of the history learning. Joebagio in Garvey and Krug (2015) stated that history lerning has the objectives as the process of internalizing the values of past incidents, in the form of origin, genealogy, collective experiences, and exemplary of historical actors. On the other hand, Widja (1988) stated that history has the functions in facing the present and the past in which without affirming the past, humans lose their grip in facing the current problems.

By knowing the objectives and functions of the history learning, what was said by a famous historian, Al Rowse (1963) was right that history is a field of study that has high educational values. However, in the reality, the history learning is known very uninteresting, boring, and not desirable. There are several reasons why the history learning can be like that. The history teaching is still engaged in dictates that make teachers less innovative (Leo Agung, 2015). Besides, the teachers cannot develop the innovative learning models of history and choose the appropriate learning approaches. Kusuma, et al. (2018) also stated that the teachers cannot choose and provide the right learning models, especially in the thematic learning that can improve the skills of the students in understanding the materials of the lesson. On the other hand, according to Kochhar (2008), the history teachers must know what must be known by the students, what must be conducted by the students, and what the students will become through the history subject.

Nithyanantham, et al. (2019) stated that in the techno-contemporary world (contemporary techno), the role of a teacher is increasingly challenging. The successful teacher is a teacher that is able to become a 'selfcreator'. This means that the teacher is able to create the learning curriculum in accordance with the learning situation in the classroom. This perspective is in line with the idea of Meulen (1987) that stated that a history teacher must be able to make a 'miracle' in the learning. The intended miracle is the history as the past incidents that have died. The teacher has a duty to bring to life a dead history as if it is living in the history classroom. This effort can be realized by developing a learning model that integrates the values through reflective learning paradigm.

The learning approach that can be used is reflective pedagogy paradigm (PPR). PPR is the learning approach that directs to value education (value oriented) (Subagya, 2010). This paradigm sees education as a whole that helps students to not only have intelligence in the field of knowledge, but also character and concern for others (social emphaty) (Suparno, 2015). There are three objectives of this educational approach in the learning known as $3 \mathrm{C}$, namely Competence (cognitive and intellectual competency), Conscience (affective ability or having the compassionate soul), and Compassion (psychomotor ability in the term of the real actions based on caring). The character value developed in PPR as stated in the Document of "Educational Quality Standards for Jesuit Schools" (Writer Team of ASJI, 2017) is leadership. There are four elements of leadership, namely self-awareness, ingenuity, love and heroism.

The research developed by the researcher was the learning model of history integrated with the leadership values through reflective pedagogy paradigm. There are 4 main syntax in this learning model, namely context, experience, reflection, action, and evaluation. The press point in this leadership learning model of history is 'reflection.' The chosen material was the battle of Mangkunegara I or Raden Mas Said. This material was chosen because it was written in the textbook of the Indonesian history for class XI of Semester I at SMA. Mangkunegara I who had the childhood name of Raden Mas Said was the king of the Duchy of Pura Mangkunegaran. The famous historian, MC Ricklefs (2015) called him as an 18th-century Javanese flamboyant leader and a Catcher of Souls because he always brought death to his enemies in the warfare. Mangkunegara I was a Javanese leader from the Mataram breed who had the dream of reuniting a divided and anti-colonialism imperialism Mataram. With the spirit of militancy and leadership, he 
Raharjo,Y.K., Sariyatun \& Warto (2019). Need analysis of learning model of history integrated with leadership values of mangkunegara i through reflective pedagogy paradigm. International Journal of Educational Research Review,4(4),617-623.

succeeded in attacking the company and despots as many as 250 battles with a duration of 16 years of resistance (1741-1757). For his leadership and struggle services, Pangeran Mangkunegara I was declared as a "National Hero of the Republic of Indonesia" in 1983 and was awarded "Bintang Mahaputra Adipurna" (Class I). In the relation to the developed learning model, the author wanted to restore collective memory and reflect the leadership values that have been exemplified by Pangeran Mangkunegara I which are still relevant to the current context under the leadership crisis occurred in Indonesia.

Based on the background above, the problems can be formulated as follows: 1) How was the history learning occurred at SMA Kolese De Britto, Yogyakarta?; and 2) How was the need analysis of the learning model product of history integrated with the leadership values at SMA Kolese De Britto, Yogyakarta?.

\section{METHOD}

This research was conducted at SMA Kolese De Britto, Yogyakarta, exactly in class XI of IPS. This school was selected because it had the characteristic of leadership based school and the learning approach of reflective pedagogy paradigm (PPR). The researcher assumed that this school would need the learning model of history integrated with the leadership values. This would be a unique case (casuistry) in the qualitative research. This research used the qualitative method with the case study approach. Creswell (2014) explained that a case study is the qualitative approach in which the researcher explores a case or phenomenon in the real life through the detailed and in-depth data collection. The sources of the data were obtained from: 1) the in-depth interview with the History Teacher of class XI named Filipus Dimas Danumurti, S.Pd and two students of class XI of IPS named Niklausius Satrio Adi and Alexander Berlian Abimanyu; 2) the distributed questionnaire for 70 students consisting of all students of class XI IPS of IPS 1, IPS 2, and IPS 3; 3) the field observation and document analysis. The field observation showed that all students at SMA Kolese De Britto were male. They were on average 17-18 years old who were Catholic, Christian, Hindu, Buddha, and Confucianism. In addition, they came from various regions in Indonesia, such as Java, Sumatra, Borneo, Sulawesi, Bali, and Nusa Tenggara.

The obtained data was analyzed through interactive analysis models. Miles and Huberman (1992) explained its stages consisting of: data collection, data reduction, data presentation, and verification or conclusion.

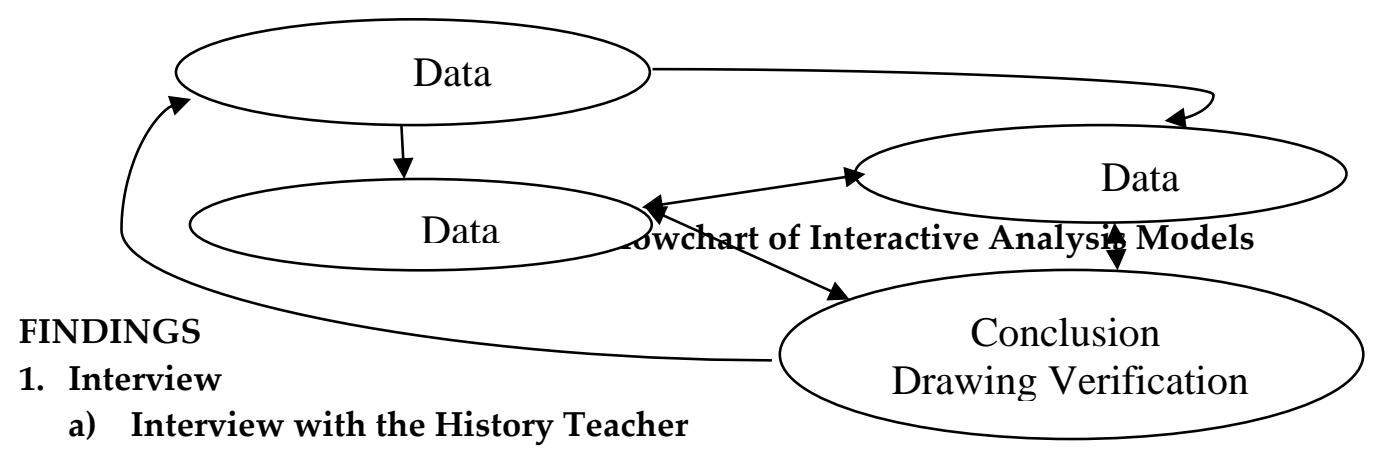

The interview was conducted with the history teacher of class XI of IPS at SMA Kolese De Britto, Mr. Filipus Dimas Danumurti, S.Pd. The interview was conducted to find out the learning models of history, the learning approaches, and the responses to the offered products of learning model. The interview was conducted on January $29^{\text {th }}, 2019$, and some additional information were obtained through electronic messages. Here is the transcript of the main interview that had been conducted in the data reduction:

Interviewer : How is the history learning that has been going on so far at school?

Informant : There is Team Teaching which is a collection of teachers from IPS group consisting of history, sociology and PKN teachers to discuss the learning that will be conducted. Learning as usual: teachers teach in front of the class, students discuss and present.

Interviewer : What learning model is often conducted by the teacher?

Informant $\quad$ : The learning model that I do usually follows Basic Competencies $(K D)$ and Core Competencies $(K I)$. Sometimes discussions and lectures are also important. 
Raharjo,Y.K., Sariyatun \& Warto (2019). Need analysis of learning model of history integrated with leadership values of mangkunegara i through reflective pedagogy paradigm. International Journal of Educational Research Review,4(4),617-623.

Interviewer : Related to the teaching, what obstacles do you experience when using the learning model of history?

Informant : The problem is a lot of materials of history, but a short duration of learning hours. So, we cannot explore and discuss the materials in depth, the impact of the learning model that I use is limited and I cannot develop a learning model.

Interviewer : : Do you know about a historical figure like Mangkunegara I?

Informant : I don't really understand about Mangkunegara I, but it seems like a great historical figure.

Interviewer : Do you know about an education or learning approach called the Reflective Pedagogy Paradigm (PPR)?

Informant $\quad$ : Yes, I know, because this school also uses that learning approach. The Reflective Pedagogy Paradigm (PPR) was formerly named the Ignatian Pedagogy Paradigm because it was taken from Ignatius' spiritual practice. This learning focuses on "reflection". The cycle consists of context, experience, reflection, action, evaluation.

Interviewer : Have you ever developed a learning model of history integrated with the leadership values of historical figures like Mangkunegara I?

Informant $\quad$ : I have never developed a learning model by teaching the leadership values of Mangkunegara I because of the limited time of the history learning so that we cannot discuss it specifically. It is actually very interesting if the learning model can be developed especially related to the leadership values that are also in accordance with the vision and mission of this school that develop leadership.

Interviewer : According to you, is that necessary to develop a learning model of history by integrating the leadership values of Mangkunegara I through the Reflective Pedagogy Paradigm? (the researcher showed the draft of the developed learning model product)

Informant $\quad$ : I think it is very necessary and important to integrate the leadership values of Mangkunegara I in the learning model of history. Because this will be useful for the students. So, the history learning is not only "memorization", but there are also the values that can be taken.

Interviewer $\quad$ : Is there any suggestion for the researcher so that the developed learning model product can be perfect?

Informant $\quad:$ My suggestion is that the developed learning model should use the learning approach of the Reflective Pedagogy Paradigm according to the characteristics of this school. The "reflection" stage in the approach will be in accordance with the developed learning model.

\section{b) Interview with the Students}

The in-depth interview was conducted with two students of class XI of IPS. However, in this article, the transcript of the interview that would be shown was the interview with the student named Niklausius Satrio Adi because of the similarity of the information. The interview with the students was conducted to find out the conditions of the history learning, and the students' responses towards the developed learning model product. The interview was conducted on January $29^{\text {th }}, 2019$. Here is the transcript of the main interview that had been conducted in the data reduction:

Interviewer : How is the history learning that has been going on so far at school?

Informant : In my opinion, the history learning in my class that has been going on so far has been quite good. The teacher puts forward the students to be able to think critically and look for sources while studying history.

Interviewer : What learning model is often conducted by the teacher?

Informant : Yes ... it is by looking for the historical facts or historical incidents, then discuss them.

Interviewer : Has history teacher ever taught the leadership values of the historical figures?

Informant : For history about the historical figure, Ever ... namely HOS Cokroaminoto. But, for the leadership values, it has never been. (Mangkunegara I)

Interviewer : Do you know about the historical figure like Mangkunegara I? 
Raharjo,Y.K., Sariyatun \& Warto (2019). Need analysis of learning model of history integrated with leadership values of mangkunegara i through reflective pedagogy paradigm. International Journal of Educational Research Review,4(4),617-623.

\begin{abstract}
Informant : Don't know much
Interviewer : Do you know about the reflective pedagogy paradigm?

Informant : I know a little, but lack depth. What I know is the learning approach of the 'reflection'

Interviewer : Do you think it is important to learn about the leadership values of Mangkunegara I?

Informant : I don't know much about Mangkunegara I, but I think it's important. Mangkunegara I, he was a hero, certainly has a valuable experience that can be taught to the younger generation.

Interviewer : In your opinion, is it necessary to develop a learning model of history integrated with the leadership values of Mangkunegara I through the Reflective Pedagogy Paradigm?

Informant : Yes, it is very necessary. Moreover, the situation of the current generation is instantaneous and the impression of the current generation who have no power struggle. Thus, it is necessary to develop a learning model integrated with the leadership values in this millennial era.
\end{abstract}

\title{
2. Result of Questionnaire Dissemination
}

The questionnaire was distributed to the students of class XI of IPS to find out the students' responses towards the learning model product of history that was developed by the researcher.

\begin{tabular}{|c|l|c|c|}
\hline No. & \multicolumn{1}{|c|}{ QUESTION } & YES & NO \\
\hline 1 & $\begin{array}{l}\text { Do you know about a historical figure named } \\
\text { Mangkunegara I or Raden Mas Said? }\end{array}$ & $14,3 \%$ & $85,7 \%$ \\
\hline 2 & $\begin{array}{l}\text { Do you know about the learning approach known as the } \\
\text { Reflective Pedagogy Paradigm? }\end{array}$ & $100 \%$ & - \\
\hline 3 & $\begin{array}{l}\text { In your opinion, is it necessary for the teacher to teach the } \\
\text { materials of the historical figures like Mangkunegara I to } \\
\text { the students and reflect the leadership values? }\end{array}$ & $\begin{array}{l}\text { In your opinion, are the materials of the historical figures } \\
\text { necessary to be taught using the interesting and } \\
\text { innovative learning model? }\end{array}$ & $81,4 \%$ \\
\hline 5 & $\begin{array}{l}\text { Do you agree that the learning model of history is } \\
\text { developed by integrating the leadership values of } \\
\text { Mangkunegara I through the reflective pedagogy } \\
\text { paradigm? }\end{array}$ & $18,6 \%$ \\
\hline
\end{tabular}

\section{DISCUSSION AND SUGGESTIONS}

The history learning is a branch of science that examines the origin and development as well as the role of society in the past based on certain methods and methodologies (Kochhar, 2008). At the high school level, history is studied as a subject while forming itself as part of social science. In the 2013 curriculum, history becomes the compulsory learning (type A) that must be taught in all classes in social studies, science, and languages. In this research at SMA Kolese De Britto, the history learning has gone well. Based on the field observations conducted on January 29-30, 2019 and the interviews with the history teachers and the students of class XI of IPS on January 29, 2019 showed that "the history learning provided space for the students to think critically". However ideally, the process of the history learning should not stop at the process of critical thinking. The history learning must also be able to take the exemplary values from the historical figures, historical incidents, and collective experiences. Ritzer (1986) conveyed this because history can be used as a source of inspirations, motivations, norms, principles or guidelines for everyday life. He also assumed that history has an important role in moral instruction and is often viewed as a branch of moral philosophy. 
Raharjo,Y.K., Sariyatun \& Warto (2019). Need analysis of learning model of history integrated with leadership values of mangkunegara i through reflective pedagogy paradigm. International Journal of Educational Research Review,4(4),617-623.

The process of finding the exemplary values in the history learning can be conducted with the development and use of the innovative learning model of history in the classroom. The learning model of history can be integrated with the values that want to be achieved. In this research at SMA Kolese De Britto, the researcher found out that this school had leadership based vision and mission. Therefore, the history learning must take part in the success of the vision and mission. However, based on the results of the observations and interviews with the history teachers and students of class XI of IPS, it can be shown that the learning model of history which integrates the leadership values has not been developed. The history teacher said that "the used learning models were limited to lecture, discussion, and presentation. These learning models were also adapted to KI and KD because of the limitation of the lesson hours". In addition, the students of class XI of IPS conveyed that "they have ever studied about the historical figures, but the learning models integrated with the leadership values have never been developed".

Quoting the opinion of Sartono Kartodirdjo (1988) that the history learning does not only stop at the process of finding historical facts, but also aims to make the students aware to raise their historical awareness. The process of raising the historical awareness can be conducted with a reflective thinking process. It is a way of thinking to look back, understand and appreciate the meaning of something. The history learning context is the meaning of the history materials in the form of the exemplary values of the historical figures, collective experiences, and historical incidents. In this research through the field observations, the specific learning approach known as the reflective pedagogy paradigm was found out. The reflective pedagogy paradigm is a learning paradigm that directs to the value orientation (value oriented). At SMA Kolese De Britto, this paradigm was used to form the students to be smart not only for the knowledge, but also have the leadership values according to the vision and mission of the school. Based on the results of the interviews with the history teachers and students of class XI of IPS, it was found out that they knew about the reflective pedagogy paradigm. Based on the results of the questionnaire distributed to all classes XI of IPS consisting of 70 respondents, the question of number 2 stated 100\% of "Yes" which means that they knew about the paradigm and became the educational paradigm at the school.

The researcher also found out about the initial understanding of the teacher and students regarding the historical figure, Mangkunegara I. Mangkunegara I was an 18th-century Javanese flamboyant leader who had the aspiration to reunite the broken Mataram (Surakarta Sunanate and Yogyakarta Sultanate). Mangkunegara I waged 16 years of resistance between the period of 1741-1757 against the Dutch colonialists and despotic rulers who were considered to ruin the Mataram kingdom. For his struggle services, Mangkunegara I was awarded the Title of National Hero by the Government of the Republic of Indonesia in 1988. The material about the resistance of Mangkunegara I was included in $K D$ 3.2, namely "analyzing the resistance strategies of the Indonesian nation to face European colonization until the $20^{\text {th }}$ century". This material was also written in the history textbook for the students of class XI of semester I, but very briefly. This becomes the teacher's duty to develop this material into the innovative learning model so that the students can take the examples of the leadership values of Mangkunegara I.

Based on the results of the interviews with the history teacher and students of class XI of IPS, the same information was obtained that "they did not recognize and understand the historical figure of Mangkunegara I". Based on the result of the questionnaire of the question of number 1, it was found out that $85,7 \%$ stated "No" which means that the students have not recognized the historical figure of Mangkunegara I. The researcher analyzed some factors why Mangkunegara I was not recognized: 1) the material about Mangkunegara I in the textbook was written very briefly because it was the sub-theme material, 2) many historical figures were studied in the textbook so that it was impossible to study all of them, 3) the history lesson hours were considered lacking, and 4) the teacher has not developed the learning model which integrates the leadership values of Mangkunegara I.

Based on those findings, the researcher tried to respond positively by offering the development product of the history learning model. The researcher developed the product of the history learning model by integrating the leadership values of Mangkunegara I through the reflective pedagogy paradigm. The researcher viewed that the developed learning model would be in accordance with the characteristic of the educational paradigm culture and the vision and mission of SMA De Britto. The result of the interview with the history teacher showed the positive response, by saying that "it was very necessary and important to integrate the leadership values of Mangkunegara I in the history learning model because this would be useful for the students". In addition, the students of class XI of IPS whom were interviewed showed the 
Raharjo,Y.K., Sariyatun \& Warto (2019). Need analysis of learning model of history integrated with leadership values of mangkunegara i through reflective pedagogy paradigm. International Journal of Educational Research Review,4(4),617-623.

positive response, by saying that "Yes, it was very necessary. Moreover, the situation of the current generation was instantaneous and the impression of the current generation who had no power struggle. Thus, it was necessary to develop a learning model integrated with the leadership values". This was also confirmed by the result of the questionnaire of the question of number $5.90 \%$ of the respondents stated "Yes" which means that the development product of the history learning model integrated with the leadership values of Mangkunegara I was needed.

The conclusions of this research were: 1) the history learning at SMA Kolese De Britto, Yogyakarta, Indonesia was already good, but the more innovative learning model was needed to be developed, and 2) the history learning model integrated with the leadership values of Mangkunegara I through the reflective pedagogy paradigm was needed. Furthermore, the limitations of this research were: 1 ) the study of the need analysis of the history learning model was only limited to one school, especially class XI of IPS, and 2) the developed history learning model was only to develop the leadership values.

The suggestion for the next researchers is that this research can be more developed becoming the learning models of history in the form of module, handout, book, tutorial video, and documentary film. It is expected that the next researches can develop other learning models of history integrated with character values of other figures both local, national, and international historical figures.

\section{REFERENCES}

Agung, L. (2015). Sejarah Kurikulum Sekolah Menengah di Indonesia. Yogyakarta: Ombak.

Agung, L. (2015). The role of social studies and history learning in junior high school in strengthening the students character. Paramita: Historical Studies Journal, 25(2), 238-246.

Creswell, J. W. (2014). Penelitian Kualitatif dan Desain Riset. Yogyakarta: Pustaka Pelajar.

Garvey \& Krug. (2015). Model-Model Pembelajaran Sejarah Di Sekolah Menengah. Yogyakarta: Ombak.

Hasan, S. H. (2012). Pendidikan sejarah untuk memperkuat pendidikan karakter. Paramita: Historical Studies Journal, 22(1), 81-95.

Kartodirdjo, S. (1988). Fungsi pengajaran sejarah dalam pembangunan nasional Jakarta: Artikel dalam Harian Kompas, 26 September 1988.

Kochhar, S. K. (2008). Teaching of history. Jakarta: Grasindo.

Kusuma, E. D. \& Gunarhadi, R. (2018). The development of problem-based quantum learning model in elementary school. International Journal of Educational Research Review, 3(3), 9-16.

Mac Gregor, J. (1978). Leadership. New York: Harper Torchbooks.

Meulen, V. D. (1987). Ilmu Sejarah dan Filsafat. Yogyakarta: Kanisius.

Miles \& Huberman. (1992). Analisis Data Kualitatif. Jakarta: UI Press.

Northouse, P. G. (2013). Kepemimpinan: Teori dan Praktik. Edisi Keenam. Jakarta: Indeks.

Ricklefs, M. C. (2015). The origin of prince mangkunegara's appellation as cathers of souls. Bijdragen tot de Taal-, Land- en Volkenkunde, 171, 543-548.

Rowse, A. L. (1963). The Use of History. London: Macmillan \& Co.

Subagya. (2010). Paradigma Pedagogi Reflektif. Yogyakarta: Kanisius.

Suparno, P. (2015). Pembelajaran Perguruan Tinggi Bergaya Paradigma Pedagogi Reflektif. Yogyakarta: Penerbit Universitas Sanata Dharma.

Vityanantham, V., Paulmony, R., \& Hasan, S. R. (2019). Self-perspective of $21^{\text {st }}$ century educators: A challenge in the globalised educational world. International Journal of Educational Research Review, 4(3), 325-333.

Widja, I. G. (1988). Pengantar Ilmu Sejarah: Sejarah dalam Perspektif Pendidikan. Semarang: Penerbit Satya Wacana.

Writer Team of ASJI. (2017). Standar Mutu Sekolah Yesuit. Jakarta: Penerbit Asosiasi Sekolah Jesuit Indonesia.

Yulk, G. A. (1989). Leadership in Organization. New Jersey: Prentice-Hall Inc.

Interview with Mr. Filipus Dimas Danumurti, S.Pd. as the History Teacher of Class XI at SMA Kolese De Britto, Yogyakarta.

Interview with Niklausius Satrio Adi as the Student of Class XI of IPS at SMA Kolese De Britto, Yogyakarta. 